\title{
Clinical Collaborations: Going Global to Advance Social Entrepreneurship
}

\author{
Authors: \\ Deborah Burand \\ Clinical Assistant Professor \\ Director, International Transactions Clinic \\ University of Michigan Law School \\ dburand@umich.edu \\ Susan R. Jones \\ Professor of Clinical Law \\ Director, Small Business \& Community Economic Development Clinic \\ George Washington University Law School \\ susanjones@law.gwu.edu \\ Jonathan $\mathrm{Ng}$ \\ Global Legal Director \\ Ashoka \\ jng@ashoka.org \\ Alicia E. Plerhoples \\ Associate Professor of Law \\ Director, Social Enterprise and Nonprofit Law Clinic \\ Georgetown University Law Center \\ aep65@law.georgetown.edu
}




\section{Short Biographies:}

Deborah Burand is a clinical assistant professor of law at University of Michigan Law School. She directs the International Transactions Clinic that she co-founded at the Law School in 2008 and she teaches in the area of impact investment lawyering. Professor Burand recently returned to the Law School after serving as general counsel to the Overseas Private Investment Corporation, the development finance institution of the United States. Professor Burand writes and lectures on issues related to international finance, microfinance and microfranchise, impact investing, social finance innovations such as social impact bonds and crowdfunding for social enterprise, and developing sustainable businesses at the base of the economic pyramid. Prior to joining the Law School faculty, Professor Burand worked in nearly equal amounts of time in the private sector (with the law firm, Shearman \& Sterling), in the public sector (with the US Federal Reserve Board and the US Treasury Department) and in the not-for-profit sector (with Conservation International, FINCA International, and the Grameen Foundation).

Susan R. Jones is Professor of Clinical Law and Director of the Small Business and Community Economic Development (SBCED) Clinic at George Washington University Law School. Before joining the Law School faculty in 1988, she was a partner in a civil private law firm. She has held teaching positions at City University of New York Law School at Queens College, where she taught lawyering skills and clinical simulations from 1985 to 1986 and as the 2004 Haywood Burns Visiting Chair in Civil Rights where she taught courses on community economic development and economic justice; at American University's Washington College of Law, where she taught legal writing; and at Antioch School of Law, where she taught in an immigration law clinic. Professor Jones is the former senior editor and editor-in-chief of the American Bar Association's (ABA) Journal of Affordable Housing and Community Development Law. In addition to holding leadership positions in the ABA, Professor Jones is the co-chair of the Association of American Law Schools (AALS), Clinical Section, Transactional Clinics Committee and a member of the executive committee of the Transactional Law and Skills Section. She is a past chair of the Clinical Section. She has written extensively about microenterprise and community economic development. Her research interests include the legal aspects of entrepreneurship, social enterprise, economic development, nonprofit organizations, and the creative economy.

Jonathan $\mathrm{Ng}$ is the Global Legal Director and in-house counsel at Ashoka. Mr. Ng oversees Ashoka's in-house legal matters for its global headquarters. He manages Ashoka's relationships with its pro bono legal counsel, which includes some of the leading global law firms. He also coordinates with Ashoka's 33 country offices on matters related to corporate structuring, governance and compliance. Ashoka believes it is uniquely situated to be a leader in developing the emerging area of law and social entrepreneurship. Because social entrepreneurs do not fit neatly into the traditional nonprofit or for-profit categories, they are constantly pushing the boundaries of the laws that apply to them. As such, Mr. Ng is working with leading law schools and practitioners to help identify and respond to legal issues unique to social entrepreneurs. Prior to joining Ashoka, Mr. Ng practiced law at White \& Case LLP in its New York office as a member of the energy, infrastructure, project and asset finance practice group.

Alicia E. Plerhoples is Associate Professor of Law and the Director of the Social Enterprise \& Nonprofit Law Clinic at Georgetown University Law Center. She has been active in the local and national social enterprise movement, often speaking about laws that best facilitate the work of 
social entrepreneurs. Professor Plerhoples' scholarship focuses on social enterprise and corporate governance. Her recent article Can an Old Dog Learn New Tricks?, 13 Transactions: Tenn. J. Bus. L. 221 (2012), examines traditional corporate law principles and how they might be adapted and applied to the flexible purpose corporation, a new corporate form that allows businesses to pursue social and environmental objectives along with profits. Her article Representing Social Enterprise, 20 Clinical L. Rev. 701 (2013), advocates a method of teaching law students about social enterprise, a subject area frequently taught in business schools but often overlooked by law schools. Her article Delaware Public Benefit Corporations 90 Days Later: Who's Opting In?, which is forthcoming in the Spring 2014 edition of the U.C. Davis Business Law Journal, presents original research on what entities are opting into the public benefit corporation-a new corporate form permitted in Delaware that requires the firm to produce a public benefit and operate in a responsible and sustainable manner. 


\title{
Clinical Collaborations: Going Global to Advance Social Entrepreneurship
}

\author{
Deborah Burand, Susan R. Jones, Jonathan Ng and \\ Alicia E. Plerhoples ${ }^{1}$
}

\section{ABSTRACT:}

In the summer of 2012, transactional law clinics from three U.S. law schools: George Washington University; Georgetown University; and the University of Michigan launched a collaboration to serve a common client-Ashoka, a global nonprofit organization that supports close to 3,000 social entrepreneurs across 76 countries. While clinic collaborations within universities happen occasionally, clinic collaborations across universities are unusual. This essay focuses on the motivations, operations, lessons, and next steps of this cross-university, clinical collaboration aimed at advancing social entrepreneurship globally. Specifically, this essay examines why the collaboration was launched, how the collaboration is structured, what the collaboration offers clients and participating law students, how the collaboration has expanded the skills and knowledge of the three clinical directors who are participating in this collaboration, where this collaboration might go next, and finally, what others might learn from this experience when contemplating their own cross-university, clinical collaborations.

1 Deborah Burand is Clinical Assistant Professor and Director of the International Transactions Clinic at the University of Michigan Law School. Susan R. Jones is Professor of Clinical Law and Director of the Small Business \& Community Economic Development Clinic at George Washington University Law School. Jonathan Ng is Global Legal Director and in-house counsel at Ashoka. Alicia E. Plerhoples is Associate Professor of Law and Director of the Social Enterprise \& Nonprofit Law Clinic at Georgetown University Law Center. 


\section{Introduction}

While clinic collaborations within universities happen occasionally, clinic collaborations across universities are unusual. In the summer of 2012, transactional law clinics from three U.S. law schools: George Washington University; ${ }^{2}$ Georgetown University; ${ }^{3}$ and the University of Michigan ${ }^{4}$ launched a collaboration to serve a common client, Ashoka, ${ }^{5}$ a nonprofit organization based in the Washington, D.C. metropolitan area of the United States that is recognized as a global leader in the field of social entrepreneurship. Ashoka was founded in 1980 by Bill Drayton who popularized the term, "social entrepreneur."6 According to Drayton,

[social entrepreneurs] have the same core temperament as their industry-creating, business entrepreneur peers. . . Social entrepreneurs focus their entrepreneurial talent on solving social problems - why children are not learning, why technology is not accessed equally, why pollution is increasing, and so on. The essence, however, is the same. Both types of entrepreneur recognize when a part of society is stuck and provide new ways to get it unstuck. They envisage a systemic change, identifying the j[i]ujitsu points that will allow them to tip the whole society onto this new path, and then persist and persist until the job is done. ${ }^{7}$

Social entrepreneurship is now a widely used term, often conveying different meanings depending on the user. ${ }^{8}$ For the purposes of this essay and our collaboration, we broaden Drayton's original definition of social entrepreneurs as those who possess a "powerful, new, system chang[ing] idea" 9 to include social entrepreneurs who use business techniques or sustainable market mechanisms to "directly address[] an intractable social need and serve[] the common good."10 Social justice is expanded through social entrepreneurship as social entrepreneurs work to instigate social,

2 George Washington University Law School's Small Business and Community Economic Development Clinic. More information about the clinic can be found at http:/www.law.gwu.edu/Academics/EL/clinics/SBCED/ Pages/Overview.aspx.

3 Georgetown University Law Center's Social Enterprise and Nonprofit Law Clinic. More information about the clinic can be found at www.socialenterprise-gulaw.org.

4 University of Michigan Law School's International Transactions Clinic. More information about the clinic can be found at www.law.umich.edu/itc.

5 Ashoka: Innovators for the Public. More information about Ashoka can be found at www.ashoka.org.

6 Caroline Hsu, Entrepreneur for Social Change, U.S. News \& World Report Online, Oct. 31, 2005, available at http://www.usnews.com/usnews/news/articles/051031/31drayton.htm (last visited Sept. 27, 2013).

7 William Drayton, The Citizen Sector: Becoming as Competitive and Entrepreneurial as Business 44 Cal. Mgmt. Rev. 120, 123 (2002).

8 See Robert A. Wexler, Effective Social Enterprise - A Menu of Legal Structures, 6 The ExEMPT Org. TAx REV. 565 (2009) ("Those of us who work with social enterprises recognize by now that there is no legal definition of social enterprise, and there is not even a uniformly recognized nonlegal definition, although there have been many valiant attempts.") See also, Alicia E. Plerhoples, Representing Social Enterprise, 20 ClinICAL L. REV. 701, 709-718 (2013) (defining social enterprise through the various business models social entrepreneurs use).

9 Drayton, supra note 7 , at 123.

10 What is Social Enterprise?, SocIAL ENTER. AlliAnce, https://www.se-alliance.org/what-is-social-enterprise (last visited Sept. 24, 2013). 
economic, and environmental change. ${ }^{11}$

Our cross-university collaboration aims to provide law students with the forum to advance social entrepreneurship globally. This essay discusses the motivations, operations, lessons, and next steps of our cross-university clinical collaboration. Specifically, this essay examines why the collaboration was launched, how the collaboration is structured, what the collaboration offers clients and participating law students, how the collaboration has expanded the skills and knowledge of the three clinical directors who are participating in this collaboration, and where this collaboration intends to turn its attention to next. Finally, we also offer advice to other clinical law faculty for structuring their own cross-university collaborations.

\section{Why collaborate?}

From the outset, we shared several key reasons for participating in this collaboration. First, we believe that Ashoka is better served by our three clinics collectively than any of the clinics individually. Ashoka is a global network of social entrepreneurs with close to 3,000 Ashoka Fellows spanning 76 countries. ${ }^{12}$ Ashoka provides "start-up financing, professional support services, and connections to a global network across the business and social sectors, and a platform for people dedicated to changing the world." ${ }^{13}$ Multiple law firms partner with Ashoka to serve its legal needs and the legal needs of its Fellows. Similarly to Ashoka's law firm partners, our three law clinics also support Ashoka and its Fellows. We also share the desire to learn from each other. Through our collaboration, we see how we each have structured the design and delivery of our legal services in a transactional clinical context and globally. We also wish to support each other in our legal work by sharing legal tools, practice methods, and other resources. Finally, and importantly, we are also motivated to work together for the purpose of facilitating and encouraging the legal academy and law students to study and contribute to the growing social entrepreneurship sector.

Our collaborative approach employs two methods: (1) students at the law schools collaborate to develop and share "best practices" for the sector through the production of legal toolkits and research that helps Ashoka further its charitable mission, and in turn, expand the field of social entrepreneurship; and (2) students, through the law clinics at each law school, also provide

11 Some social enterprises use not-for-profit models for their operations; other use for-profit models. Still others use hybrid models that pair not-for-profits with for-profits in ownership and governance structures, or through contractual relationships. The decision as to how best to structure a social enterprise often turns on a variety of issues that go far beyond just the simple question of whether the founders intend to make money. Some of the most common issues range from the mission or motivation of the enterprise's founders, source of capital available to the enterprise (initially and over the longer term), size of the potential market (hence scalability of the enterprise), and founders' desire for control. See Jim Fruchterman, For Love or Lucre, STANFORD Soc. INNOV. REV. $42-47$ (2011) (describing key business issues that will likely shape a social enterprise's choice of legal structure). Contra Albert Hyunbae Cho, Politics, Values and Social Entrepreneurship: A Critical Appraisal, in Social ENTREPRENEURSHip 34, (Johanna Mair, et al. eds., 2006) (challenging social entrepreneurship approaches for their potential to create two problems: "they may coercively impose entrepreneurs' visions of terminal objectives and the means appropriate to achieve them, and they may yield incomplete, even perverse solutions that ignore fundamental drivers of social problems.”); Fredrik O. Andersson, Social Entrepreneurship as Fetish, NonProfit QuArterly, Apr. 11, 2012 available at http://www.nonprofitquarterly.org/management/20140. social-entrepreneurship-as-fetish.html (last visited Dec. 12, 2013) (questioning the promise of social entrepreneurship and arguing that because of "the lack of rigorous research and evidence of what it is, what works, and what doesn't, it appears premature to urge nonprofits to become more entrepreneurial.")

12 Ashoka is registered as a 501(c)(3) tax-exempt organization in the United States.

13 AshoKa: InNovators for the Public, https://www.ashoka.org/about (last visited Dec. 13, 2013). 
business and transactional legal services to Ashoka and individual Ashoka Fellows who run social enterprises within Ashoka's network. The social enterprises that the clinics serve are intent on making positive economic, social, and/or environmental impacts on the communities in which they operate. ${ }^{14}$ Transactional lawyers have an important role to play in facilitating the social enterprise movement. The clinics at Michigan, George Washington, and Georgetown engage law students in this multi-layered endeavor as they undertake legal representation, strategic planning, and advocacy on behalf of Ashoka and Ashoka Fellows in the U.S. and abroad.

In addition to these shared objectives and methods, each clinic in this collaboration has its own unique reasons for participating in this tripartite clinic collaboration. The primary motivations of each of the clinics follow. First, however, this essay begins with an explanation of why our client Ashoka decided to work with all three clinics collectively, instead of engage each clinic separately.

\section{a. Ashoka's Outreach to the Next Generation of Lawyers}

Ashoka sits in a unique position to help advance the evolving area of law and social entrepreneurship. Ashoka has built the world's largest association of leading social entrepreneurs through an extensive network of Ashoka Fellows. Since 1980, Ashoka has elected close to 3,000 Ashoka Fellows spanning 76 countries. Ashoka has an extensive international network that supports the unique mission and objectives of its Fellows, in particular, and social entrepreneurs, in general. Given Ashoka's position and objectives, Jonathan Ng, Ashoka's Global Legal Director, recognizes social entrepreneurs' profound need for access to quality legal advice from lawyers who understand the concept of social entrepreneurship and who are particularly creative and entrepreneurial themselves. Furthermore, many social entrepreneurs start and grow new organizations, creating a particular need for transactional legal support.

Such transactional legal support may consist of advising on entity formation and other general corporate matters. The organizations that social entrepreneurs create sometimes do not fit neatly within the traditional legal confines of a nonprofit or for-profit entity. A social entrepreneur, for example, may seek to generate revenue through charitable grants and donations while also developing earned income revenue streams by providing services for fees or selling products. As such, an Ashoka Fellow's choice of legal entity may necessitate a hybrid model whereby an organization consists of both a nonprofit and for-profit entity, either working in parallel as affiliates or under a membership structure (i.e., this could take the form of a shared governance structure or possibly even a parent/subsidiary-like structure ). Once an Ashoka Fellow's organization is established, he or she must also deal with other typical legal issues such as entering into contracts, applying for trademarks and protecting other intellectual property, hiring staff, and establishing good governance and internal policies. ${ }^{15}$ Although many of these legal issues may not differ from a typical nonprofit organization or other type of start-up entity, the approach to lawyering for

14 Ashoka selects Fellows through a rigorous screening process through which Ashoka evaluates the social entrepreneur's creativity, ethical fiber, entrepreneurial quality, and potential social impact of the idea or solution proposed. For a full list of Ashoka Fellows and more information about their work, see AsHOKA: INNOVATORS FOR THE PUBlic, https://www.ashoka.org/fellows (last visited Dec. 13, 2013)

15 Many of these needs are within the areas of expertise of one or more of the collaborating clinics. For example, students in George Washington's SBCED Clinic may be certified to file trademark applications on behalf of clinic clients through the US Patent and Trademark Office Pilot Law School Certification Program. 
social entrepreneurs may differ because of the double- or triple-bottom line objectives of the organization (i.e., a social and/or environmental mission in addition to a profit-driven mission).

Further, as the area of social entrepreneurship continues to evolve, so too have the laws affecting social entrepreneurship. Examples include the creation of new forms of legal entities to accommodate social enterprises. ${ }^{16}$ Open-source licensing also can facilitate innovation in social entrepreneurship. As the law begins to catch up with what social entrepreneurs are doing on the ground, lawyers will need to understand these laws and better understand the unique needs of social entrepreneurs to more effectively counsel them. As such, Ashoka believes in developing a community of lawyers knowledgeable about, and engaged in, the social entrepreneurship space. Ashoka has created an extensive network of pro bono legal partnerships with some of the leading global law firms such as Latham \& Watkins, Hogan Lovells, and Linklaters, among others, that assist both Ashoka and Ashoka Fellows. To expand this community, Ashoka believes in investing in law students who will become the new generation of lawyers to work with an ever-emerging client base of social entrepreneurs. For this reason, Ashoka has piloted the collaboration with law school clinics that teach law students the transactional lawyering skills required to assist social entrepreneurs.

\section{b. Why The University of Michigan's International Transactions Clinic?}

When the International Transactions Clinic (ITC) was launched at the University of Michigan Law School in the fall of 2008, it was the first of its kind in the world - a law clinic focused exclusively on providing legal services to support cross-border transactions conducted by organizations seeking to change the world for the better. When announcing the launch of the ITC, then Dean Caminker explained, "This is an exciting opportunity to involve a new generation of bright legal minds in cross-border transactions that will train our students for a lifetime of international business dealings, and that can also make an enormous difference in the lives of the people in the developing world."17

The ITC is living up to its tag line: "doing good by doing deals - globally." Since its launch in 2008, the ITC has enrolled nearly 80 students who, in turn, have advised clients in the conduct of over 100 transaction matters. Initially the ITC focused on serving clients that worked in the microfinance sector. Now, five years later, the ITC's clients range from for-profit to not-for-profit

16 Social enterprises have a growing number of legal structures available to them in England and Wales, and the United States, for example. In England and Wales, there are two legal forms that were created specifically for social enterprises - community interest companies ("CICs") and charitable incorporated organizations ("CIOs"). See Morrison Foerster \& TrustLaw Connect, "Which Legal Structure is Right for My Social Enterprise? A Guide to Establishing a Social Enterprise in England and Wales” (April 2012) (on file with authors). In the United States, a growing number of state legislatures have enacted legislation specifically designed for social enterprises, such as low-profit limited liability companies (L3Cs), flexible purpose corporations (in California), and benefit corporations (in 19 states and Washington, DC). See Carter G. Bishop, Fifty State Series: L3C $\mathcal{F}$ B Corp Legislation Table, Suffolk University Law School Legal Studies Research Paper Series, Research Paper 10-11 (July 10, 2012); State by State Legislative Status, BenEFITCORP. NET, http:/www.benefitcorp.net/state-by-state-legislative-status (last visited Dec. 11, 2013); see also Morrison Foerster \& TrustLaw Connect, "Which Legal Structure is Right for My Social Enterprise? A Guide to Establishing a Social Enterprise in the United States" (May 2013) (on file with authors).

17 Evan H. Caminker, Branch Rickey Collegiate Professor, Professor of Law, and former Dean of the University of Michigan Law School (announcing the launch of the International Transactions Clinic in 2008). 
organizations, from start-up companies to well-established businesses, and from impact investors to social enterprises. Some ITC clients are based in Ann Arbor, Michigan; others are based in such places as Bangladesh, Kenya, and Tajikistan. ${ }^{18}$ However, what the ITC's clients all hold in common is an international focus and passion for improving the world with innovative business models, products, and services.

Jonathan $\mathrm{Ng}$ and his colleagues at Ashoka approached ITC Director Deborah Burand in the spring of 2012 after hearing her speak at a conference about the ITC's pro bono representation of social enterprises and impact investors engaged in cross-border transactions. They asked if the ITC could provide legal services to Ashoka and its Globalizing Fellows ${ }^{19}$; Burand quickly agreed. The clinic's physical distance from Ashoka (its headquarters are based in Northern Virginia) and Globalizing Fellows (who are located around the world) was not an impediment as the ITC was used to working with clients that were not based in Michigan (or in the United States, for that matter). The bigger issue facing the ITC was that of capacity. At the time of the ITC's initial discussions with Ashoka, Ashoka had more than 50 Globalizing Fellows. The ITC could not serve all of these new Ashoka-related clients at once while also providing legal services to its existing client population.

This capacity problem coincided with another issue facing ITC Director Burand: the ITC's exclusive focus on working internationally made it an outlier with respect to other transactional law clinics in the United States and elsewhere in the world. Burand felt professionally isolated as a result. A few weeks after the ITC and Ashoka began discussing a potential collaboration, Burand spoke at a transactional law clinic conference in the United States and inquired if any other U.S.-based transactional law clinics had considered pursuing international deal work. At this conference, Burand connected with the other professors that now participate in the tripartite clinical collaboration. Shortly upon returning to Michigan, Burand called Ashoka and asked $\mathrm{Ng}$ if he would be open to piloting a clinic collaboration with transactional law clinics based at Michigan, Georgetown, and George Washington Law Schools. Given Ashoka's emphasis on developing ecosystems that advance social entrepreneurship, Ng agreed.

During the first year of the collaboration, the ITC took on three transactional matters-one for Ashoka as the client and two for Ashoka Globalizing Fellows based in Kenya. The legal services the ITC provided to these clients varied greatly and included, among other things: (i) developing a compliance guide to raise awareness about and ensure compliance with U.S. laws and regulations in the areas of anti-money laundering, combatting the financing of terrorism, foreign corrupt practices, and economic sanctions; (ii) creating microfranchise agreements easily understood by small shopkeepers in rural Kenya; and (iii) analyzing entity formation choices and funding agreements necessary for expanding a social entrepreneur's business into South Sudan.

18 The ITC does not offer legal advice about the laws of countries outside the United States. Rather, much like global law firms, the ITC limits its role on cross-border transactions to that of acting as international counsel, and looks to local counsel to provide local law advice as appropriate.

19 Ashoka's Globalizing Fellows are a subset of Ashoka Fellows within Ashoka's networks whose "ideas have the greatest potential to catalyze global systems change." John Converse Townsend, Going Global: Ashoka Globalizer Fellows are Off to Vienna from Nov. 5 to Nov. 7, Ashoka Blog (Nov. 3, 2011), available at: https:// www.ashoka.org/story/going-global-ashoka-globalizer-fellows-are-vienna-nov-5-7 (last visited Sept. 25, 2013). 


\section{c. Why Georgetown's Social Enterprise and Nonprofit Law Clinic?}

The Social Enterprise and Nonprofit Law Clinic (SENL Clinic) was not yet operational when its director, Alicia Plerhoples, began participating in the collaboration. In Spring 2013, Plerhoples taught an experiential seminar on social entrepreneurship at Georgetown in which law students worked with Ashoka to develop legal case studies of Globalizing Fellows and a social entrepreneur recommended to Ashoka by one of its law firm partners. ${ }^{20}$ Ashoka tasked the law students with writing legal case studies that illuminate some of the legal issues that social enterprises face, and identifying how the lawyers of these social enterprises are molding current legal regimes for their clients' social purposes. Working in teams of two, Georgetown law students conducted due diligence to learn about the social entrepreneurs who agreed to take part in the case studies. The students conducted in-depth interviews of each participating social entrepreneur and also interviewed the lawyers who assisted the social entrepreneurs in their work. Through the class seminar, the law students learned about social entrepreneurship generally and also discussed the many legal issues that social entrepreneurs face as they attempt to launch, grow, and scale their organizations. With that background knowledge in hand, the law students analyzed their research and drafted the legal case studies.

The first legal case study explores the innovative capital raising models undertaken by a social enterprise that provides solar power to developing countries. The case study discusses the securities laws that the social enterprise navigated as it sought to crowdfund ${ }^{21}$ its operations, as well as the founding entrepreneurs' decision to join an accelerator whose management team understood the organization's social impact mission (as opposed to an accelerator that prioritizes fast-growth startups with a potential for high profit). The second legal case study details the organizational structure and governance methods used by a social enterprise that works with Mexican communities to develop wind farms on their most valuable community asset - land. The legal case study discusses how the social mission of the social enterprise was anchored through legal mechanisms (including corporate form) and communities were engaged and mobilized through direct participation in the social enterprise's decision-making process.

These legal case studies were undertaken under the auspices of the first objective of our collaboration: the production of legal tools and research that helps Ashoka further its charitable mission, and in turn, expand the field of social entrepreneurship. Georgetown law students presented the final case studies to participants within Ashoka's network in May 2013, and at the Annual Conference on Social Entrepreneurship at New York University's Stern School of Business in November 2013. Since then, the case studies have been shared through the Ashoka network and elsewhere as an educational tool for other organizations facing similar legal issues.

With this experiential seminar as its starting point, the SENL Clinic began its first semester of operation in August 2013. SENL Clinic's goals are to: (1) teach law students the materials, expectations, strategies, methods, and lexicon of transactional lawyering, as well as an appreciation

20 Two of the legal case studies are available for download at www.socialenterprise-gulaw.org.

21 "Crowdfunding is by definition, "the practice of funding a project or venture by raising many small amounts of money from a large number of people, typically via the Internet." Tanya Prive, What is Crowdfunding and How Does it Benefit the Economy?, Forbes Blog, November 27, 2012, available at http://www.forbes.com/sites/ tanyaprive/2012/11/27/what-is-crowdfunding-and-how-does-it-benefit-the-economy (last visited September 27, 2013). 
for how transactional law can be used in the public interest; (2) represent social enterprises and nonprofit organizations in corporate and transactional legal matters; and (3) facilitate the growth of social enterprise in the Washington, D.C. area. As the collaboration between Ashoka and the law clinics has developed, SENL Clinic has undertaken direct legal representation of Ashoka Fellows on transactional and corporate legal issues. Ng also participates in SENL Clinic's seminar; he serves as a guest lecturer and teaches clinic students about the global social enterprise sector generally as well as discusses his role as an in-house social enterprise lawyer for Ashoka.

Participating in the collaboration provides the SENL Clinic with a source of established social enterprise clients with complex legal issues to challenge clinic students. ${ }^{22}$ It also introduces students to the social entrepreneurship sector and a means of using transactional lawyering in the public interest. Most business schools in the United States now have courses in social entrepreneurship; however, only a handful of law schools have corresponding classes. ${ }^{23}$ Many transactional law clinics (such as George Washington's Small Business and Community Economic Development Clinic) have engaged social enterprises since such clinics began in the 1970s, although it has not always been labeled as such. Thus, for now, law students are most likely to encounter social enterprise in a clinical course representing a social enterprise, nonprofit, or small business. The SENL Clinic attempts to explicitly engage students in the study of social enterprise through the representation of such clients.

\section{d. Why George Washington's Small Business and Community Economic Development Clinic?}

When asked to participate in the collaboration, Small Business and Community Economic Development Clinic (SBCED Clinic) Director Susan Jones welcomed the opportunity to expand the reach of her well-established clinical program. ${ }^{24}$ Since its inception in 1977 the SBCED Clinic has represented microbusinesses, nonprofit organizations, and artists. Although the SBCED Clinic has long identified and served several clients working in the social entrepreneurship sector, the clinical collaboration with Ashoka provided the chance to include social entrepreneurship into the clinical curriculum in a more robust manner. In addition, the collaboration allowed SBCED Clinic students to link local community economic development (CED) issues with international and domestic social enterprise concerns. In the U.S., CED emerged primarily during the Civil Rights era (1950s-1970s) in response to "tenacious poverty and the need for affordable housing, good

22 For a discussion of complex transactional legal work within a clinical setting and its pedagogical benefits to students, see Laurie Hauber, Complex Projects in a Transactional Law Clinic, 18 J. Affordable Housing \& Community Dev. L. 247 (2009).

23 For example, Deborah Burand now teaches a seminar on impact investment lawyering at the University of Michigan Law School in addition to directing the ITC. This seminar examines legal issues that are likely to arise in the life cycle of investments into social enterprises from the perspective of counsel to the investor (the impact investor) and counsel to the investee (the social enterprise).

24 For a description of the SBCED clinic's operations and goals, see Susan R. Jones, Small Business and Community Economic Development: Transactional Lawyering for Social Change and Economic Justice, 4 CLINICAL L. REV. 195 (1997). See also Susan R. Jones \& Jacqueline Lainez Enriching the Law School Curriculum: The Rise of Transactional Legal Clinics in US Law Schools, __ WASH. U. J. L \& Soc. PoL'Y __ (forthcoming 2013). 
jobs and affordable health care, and other quality-of-life matters needed for human existence." 25 Overall, CED encompasses "a wide range of economic activities ...[including] small business development and involves community building beyond that which is purely economic."26 Today, CED is structurally aligned with the social, economic, and environmental (i.e., triple-bottom line) of social enterprise and has the capacity to link local economy issues to global economic concerns.

During the initial phases of the collaboration, the SBCED Clinic represented Ashoka and created a Legal Audit Checklist for Social Entrepreneurs that is now widely available to Ashoka Fellows. The Legal Audit Checklist lists topics, identifies legal issues, and poses questions for social entrepreneurs to discuss with legal counsel. By providing social entrepreneurs with the right questions to ask their legal counsel and educating them on legal terminology, the Legal Audit Checklist helps social entrepreneurs establish a productive attorney-client relationship and saves the social entrepreneur time and money that might otherwise be spent on legal fees. Next, students in the SBCED Clinic represented a nonprofit organization founded by an Ashoka Fellow whose mission is teacher training and education reform. The SBCED Clinic also directly represents Ashoka on contractual matters. Going forward, students in the SBCED Clinic will also represent other social enterprises founded by Ashoka Fellows.

\section{How is the clinic collaboration structured?}

Our clinic collaboration has two tiers. First, each clinical program represents Ashoka as a client or community partner. The ITC and SBCED have established an attorney-client relationship with Ashoka and provided legal services to Ashoka directly. All three clinics also partner with Ashoka to produce research, legal toolkits, and other materials useful to the social entrepreneurs that Ashoka supports. Sometimes, $\mathrm{Ng}$ directs the clinics to produce these materials, but just as often, we pitch ideas to Ng regarding legal projects that Ashoka Fellows might find useful. Second, Ashoka refers its Fellows as needed to one of the clinics. The match is made based on the client's needs and the clinic's availability and specialty. In these cases, the clinic establishes an attorneyclient relationship directly with the Ashoka Fellow, which includes entering into an engagement letter with the client. In each attorney-client relationship (i.e., between a clinic and Ashoka, or between a clinic and an Ashoka Fellow), client confidentiality is maintained. That is, once the match is made or the project is advanced, the clinic directors do not discuss client confidences amongst each other unless the client (either Ashoka or an Ashoka Fellow) has provided informed consent to waive confidentiality. ${ }^{27}$ Moreover, matches are made based on a clinic's particular expertise and core competencies; at the outset of the collaboration each clinic director provided $\mathrm{Ng}$ with a description of her clinic's legal services.

An additional, intentional design of this collaboration is the clinic directors' coordination of efforts in order to ease any administrative burden that $\mathrm{Ng}$ might feel had he worked with each clinic separately. That is, $\mathrm{Ng}$ does not have to meet with each clinic director separately to pitch

25 Roger A. Clay Jr. \& Susan R. Jones, Building Healthy Communities: A Guide to Community Economic Development for Advocates, Lawyer and Policymakers, American Bar Association, 2009.

26 Id.

27 Because separate attorney-client relationships are formed within the collaboration, each clinic operates according to its own governance principles and under its own malpractice or professional liability insurance. The clinics are not responsible for each other's legal work. 
projects or clients. Every quarter, the clinic directors and $\mathrm{Ng}$ meet as a group to discuss the collaboration, new ideas, ongoing legal projects, and potential clients. These regular check-ins facilitate the collaboration by reducing administrative overlap and by maintaining transparency and accountability in our collective work, while also keeping us on task to achieve our collective mission.

\section{What does the clinic collaboration offer students and Ashoka clients?}

In addition to gaining competence in the many lawyering skills typically taught in transactional law clinics, ${ }^{28}$ the collaboration provides students with the opportunity to contribute to the social enterprise sector and represent established social enterprises that have complex legal needs. The clients of the clinics gain lawyers who are attune to the particular legal needs of social enterprise clients.

Transactional lawyers have an important role to play in facilitating social enterprise, similar to their integral role in small business development, the nonprofit sector, and community economic development:

Business lawyers facilitate economic activity. They structure transactions and navigate laws and regulations for the benefit of their organizational clients. A sophisticated business lawyer must understand the client's business as well as the context and regulatory framework in which the client operates. The emerging sustainability field thus requires that business lawyers be able to articulate, advocate for, and take into account the client's sustainability goals when structuring a transaction or otherwise facilitating the client's business strategy or operations. Because sustainability goals are difficult to shape into a viable business model, business lawyers must help their social enterprise clients by spotting routine and novel legal issues, navigating legal gray areas, fitting sustainability initiatives into the existing legal and regulatory framework, and assisting in creating a new framework that can accommodate sustainability goals. ${ }^{29}$

The clinic collaboration offers law students the opportunity to engage in this important work and contribute to the social enterprise field through direct representation of social enterprise clients as well as by acting as advocates for the sector. In some ways, transactional law clinics and their participating law students are ideally positioned to assist the growing social enterprise sector,

28 Lawyering skills learned in the typical transactional law clinic have been well documented and will not be repeated here. See, e.g., Alicia Alvarez \& Paul Tremblay, Introduction to Transactional Lawyering PRACTICE (2013) (discussing these transactional lawyering skills: interviewing, transaction planning, counseling organizational clients, negotiating transactions and contracts, drafting transactional documents, and navigating ethical issues in transactional practice); Susan D. Bennett, Embracing the Ill-Structured Problem in a Community Economic Development Clinic, 9 CLINICAL L. REv. 45 (2002) (discussing problem-solving in the transactional context); Ronald J. Gilson, Value Creation by Business Lawyers: Legal Skills and Asset Pricing, 94 YALE L.J. 239 (1984); Karl S. Okamoto, Teaching Transactional Lawyering, 1 DreXel L. Rev. 69 (2009); Lisa Penland, What a Transactional Lawyer Needs to Know: Identifying and Implementing Competencies for Transactional Lawyers, $5 \mathrm{~J}$. Ass'n Legal Writing Dirs. 118 (2008).

29 Plerhoples, supra note 8, 739-740 (defining "sustainability" in the corporate sector as the strategic pursuit of social, environmental, and financial value creation to facilitate the needs of present and future generations; as opposed to the pursuit of financial value singularly to the detriment of present and future generations). 
locally and globally. Law students who participate in such clinics have the interest, capability, and time to (i) reflect on the legal work they perform for individual social enterprise clients, (ii) aggregate information across social enterprise clients, (iii) identify patterns of legal needs and deficiencies in the social enterprise sector, and (iv) develop strategies and solutions to satisfy the collective interests of the social enterprise sector. One Ashoka Globalizing Fellow echoed this view after working with the ITC during the 2012-2013 academic year:

The structure of the [International Transactions] clinic is great for what we need as high-growth enterprises, because it allows for the time and dedication to get to know our businesses and culture and risks, rather than rushing to template solutions that really aren't a good fit. ${ }^{30}$

"Client-centered lawyering," a pedagogical method used by all three law clinics, also facilitates student learning and clients' achievement of their individual goals. Client-centered lawyering is a lawyering method that emphasizes the client's voice, decision-making abilities, values, and goals. ${ }^{31}$ The client-lawyer relationship is collaborative rather than hierarchical. Client-centered lawyering is a skill that social enterprises, in particular, require given their blending of profit-motives with philanthropic motives. It is also a skill that students can use to distinguish themselves as social enterprise lawyers.

At Ashoka's Future Forum in May 2013, Plerhoples spoke with social entrepreneurs within Ashoka's network about the role of a transactional lawyer in facilitating the social enterprise's work. A key issue that was expressed by social entrepreneurs at this Future Forum panel is the need for lawyers who (i) understand the multiple bottom lines (financial, social and environmental returns) of the social enterprise, (ii) view the representation as an opportunity to shape law and regulation for the social enterprise's benefit, and (iii) charge reasonable and affordable rates. Some audience members had encountered lawyers that they characterized as inflexible "naysayers" who were unable to "think outside the box" and failed to fully appreciate the missions of their social enterprise clients.

In stark contrast, the law clinics teach students to engage in client-centered lawyering. Law students are taught to (i) study an organizational client's mission, operations, and goals, (ii) see problems from the client's perspective, (iii) help the client identify and assess benefits and risks inherent in proposed actions, (iv) facilitate the client's decision-making process, and (v) help the client achieve its goals. By adopting a client-centered approach, students must minimize their own assumptions and think creatively to achieve novel or unlikely solutions to a problem. Students also learn about social enterprise business and funding models as a means of understanding the industry they serve. By adopting a client-centered approach, our law clinics and students are better able to serve social enterprise clients that are often pushing the boundaries of the law to fit their multiple bottom line missions.

30 Madison Ayer, Director, Honey Care Africa

31 Binder et Al., Lawyers as Counselors: A Client-Centered Approach (1991) (describing client-centered lawyering and illustrating its application to the attorney-client relationship). 


\section{What does this clinic collaboration teach the three participating clinical directors?}

At a most basic level, our collaboration teaches us to "walk our talk" and to reflect on what we ask our students to learn - that collaboration is "a process in which respectful interaction brings the talents of all parties to bear on a problem." 32 As Professor David Chavkin observes, our students collaborate with their peers and with their clinical supervisors in rounds and in supervision meetings. ${ }^{33}$ They tend to use one of three collaborative models, "input collaboration" (one team member comments on another team member's work); "parallel collaboration" (team members divide tasks); and "true collaboration" (all team members brainstorm at all phases of the collaboration - drafting, brainstorming, and final implementation). True collaborators discuss goals, strategies, and other significant issues so that the viewpoints and insights of all collaborators are acknowledged, choices are explicitly identified and strategies are developed based on the relevant choices. Indeed, true collaboration maximizes the benefits of each member's experience and knowledge brought to the enterprise. ${ }^{34}$

Research shows that there are myriad benefits of collaboration. Collaboration improves the outcome of work product, honors the life (and in this instance, the teaching experiences) of each team member, and highlights the fact that that a range of life experiences lead to more effective advocacy for clients. Collaboration also recognizes differences as strengths, increases motivation, and reduces anxiety. ${ }^{35}$ In our collaboration, we are learning not only a great deal from our clients about the need for legal structures to support hybrid business entities, we also are learning from different transactional clinic design choices, different lawyering experiences, and clinical teaching methods.

Each of these three clinics is at a very different stage of development. George Washington has a mature clinic. The SENL Clinic at Georgetown is in its start-up phase. The ITC exists between the two clinics, having just celebrated its 5 th year anniversary. As clinicians with varying levels of law teaching experience, we also are learning from each other. To illustrate, Jones, who leads the most mature clinical program of the three clinics, learned a great deal from Burand and Plerhoples as they grew and developed their programs. One specific example of a lesson learned is how to incorporate outside lawyers in a clinic, which ITC has successfully done. ${ }^{36}$ Burand, in turn, has learned from her collaborators how transactional clinics are particularly well suited to providing

32 David F. Chavkin, Clinical Legal Education: A Text for Law School Clinical Programs, at 88 (2002).

33 Id.

34 Id. at 88-89.

35 Id at 86-87.

36 The ITC makes use of nearly a dozen practicing lawyers in its work. These practicing attorneys, together with fulltime law faculty of the ITC, supervise ITC law students. And, for more complex cross-border transactions, these practicing attorneys and their collaborating law firms offer legal advice on issues that are beyond the scope of the ITC - such as tax structuring advice for cross-border investment vehicles, for example. In these instances, the law firms often structure their collaborations with the ITC as a co-counseling arrangement, whereby the law firm enters into a separate engagement letter with the client. 
action research and policy advice that advances broader sectorial interests. ${ }^{37}$ As the newest clinician, Plerhoples has gained mentors in Jones and Burand, consulting them on both complex and mundane administrative and pedagogical issues. Because of our collaboration, we each have an additional colleague to call upon for professional advice.

\section{What are the challenges of the collaboration?}

Despite the early successes of our collaboration, we also recognize the challenges. First, despite our collaborative efforts, we do not have the collective capacity or competencies to assist Ashoka on all its legal matters, or to assist all Ashoka Fellows on their legal matters. The three clinics involved have a dual role-both teaching students and serving clients. Therefore, our clients' legal needs must be balanced against our students' educational needs. Students conduct the client work, and each clinic director builds in the necessary time for careful supervision of student work and reflection by students on their work and clinical experiences. This valuable, but time-consuming pedagogical method constrains the number of clients the clinics can represent. Moreover, each clinic has its own constraints related to its pedagogical and service-oriented objectives. While Ashoka Fellows most often operate globally, both SBCED and the SENL Clinic are also committed to serving nonprofit organizations and small businesses locally. For this reason, international organizations do not constitute these two clinics' entire client base. There are also some legal matters that fall outside the clinics' varying scopes of expertise, such as securities law. ${ }^{38}$

Finally, a major challenge relates to the legal practice rules of different jurisdictions. Where the clinic directors (and other clinic faculty) are licensed or authorized to practice is taken into account when matching an Ashoka Fellow with a clinic. If a matter arises in a jurisdiction in which a clinic director or clinic faculty member is not authorized to practice, the clinics may still represent the client if they can limit the focus of the legal work to satisfy practice requirements, or they can work with local co-counsel. For example, the ITC collaborates with attorneys at law firms that can tap into their global network of attorneys. The ITC also has started to co-counsel with LLM graduates of the University of Michigan Law School that have returned to their home jurisdictions. Ashoka is also able to connect the clinics with its network of law firms. Importantly, we are each aware of and respect the limitations of our collaboration.

\section{What's Next?}

Social entrepreneurship is growing in the world. The number of those investing in such social enterprises (often called "impact investors") also is growing. Many of these transactions are

37 Prior to this clinic collaboration, Director Burand focused much of the ITC's work on specific client deal engagements. She then observed first-hand the "action research" that the other two clinics were conducting for Ashoka and its Fellows. Accordingly, before the end of the first year of the clinic collaboration, law students in the ITC were providing public comments on draft U.S. regulations regarding investments into Myanmar where the students identified possible confusion that could arise when applying these regulations to investments made into Myanmar by hybrid (for-profit and not-for-profit) organizations.

38 The clinic each work with outside attorneys, to varying degrees, to provide additional legal services where possible. 
taking place across national borders. ${ }^{39}$ Transactional law clinics can play an important role in developing lawyers who understand the unique risks and opportunities in this sector and can bring international transactional legal skills to bear on these new types of deals. Knowledge of the local laws relevant to these transactions also is important. Finding local counsel that understands the nuances of transactions that are intent on generating multiple types of returns can be challenging. Given that so many social enterprises are operating in emerging markets, there is an obvious need for law schools in such markets also to help grow the next generation of lawyers capable of advising social entrepreneurs and impact investors about the laws of their respective jurisdictions. This is a particularly significant role that law schools can play in countries where there is a more limited culture of pro bono representation by law firms. Accordingly, extending our clinical collaboration across borders to transactional law clinics in other countries seems a natural and important next step.

Thus far, we have each taken on legal projects and client representations and enlisted our clinic students to manage the legal projects and represent the Ashoka-referred clients, but our students in each clinic have not interacted with each other. That is, students from each of the legal clinics interact directly with $\mathrm{Ng}$ or the Ashoka Fellow, but they have not interacted with students from the other collaborating clinics. Our interaction has only occurred at the director-level. We hope to build cross-university collaboration among our students in the near future. From there, we hope to expand our clinical collaboration to create a network of law school clinics from around the world and adopt additional clients beyond Ashoka and Ashoka Fellows. We envision a network in which clinic directors and law students from multiple law schools co-counsel with each other - crossing borders to provide legal advice that supports international investments in social enterprises. For example, the SENL Clinic represents a U.S.-based nonprofit organization that supports Rwandan cooperatives. A network of law school clinics working collaboratively would allow U.S. clinic students to work with Rwandan-based law students to serve the legal needs of our cross-border social enterprise client.

\section{Lessons Learned}

Despite the early stage of our collaboration, we hope that our clinical collaboration provides useful lessons for other clinicians to work collaboratively and across universities. To launch this collaboration, we undertook the following initial steps, and offer them as advice to other clinical law faculty seeking to engage in clinical collaborations:

Identify a client whose legal needs are too numerous and/or are too varied to be served by a single transactional law clinic;

1. Obtain the client's agreement to be served by a consortium of clinics;

2. Identify each transactional law clinic's "sweet spot" of legal services to determine

39 A 2011 survey of over 2,200 impact investments conducted by J.P. Morgan and the Global Impact Investment Network (GIIN) found that nearly two-thirds of the number of impact investments surveyed were made into emerging markets $(67 \%$ were made into emerging markets, $31 \%$ were made into developed markets, and $2 \%$ were made globally). On the other hand, the notional values of these surveyed impact investments skewed toward developed markets (44\% in emerging markets, $53 \%$ in developed markets, and $4 \%$ globally). See Yasmin Saltuk, Amit Bouri, Giselle Leung, "Insight into the Impact Investment Market: An in-depth analysis of investor perspectives and over 2,200 transactions," at 12 (J.P. Morgan's Social Research, December 14, 2011) available at: www.thegiin.org. 
how and when to allocate work across the collaborating clinics. This necessarily involves a discussion of each clinic's structure, design, client selection process, timeline for accepting legal work, etc.;

3. Develop separate engagement letters with the client for each clinic;

4. Discuss confidentiality concerns and respect attorney-client boundaries (e.g. Ashoka might engage the ITC on a particular matter that the ITC then keeps confidential, even amongst the collaborating parties; we also never discuss Ashoka Fellow client matters with $\mathrm{Ng}$ or other Ashoka representatives unless expressly authorized); and

5. Establish regular check-in points so that the collaborating law clinics can discuss ongoing legal products, continue to look for new opportunities to collaborate, pitch project ideas to the client, and obtain feedback from the client as to the value of the collaboration.

Additionally, although not every clinical collaboration will follow a similar model, there are three lessons that likely are critical to success. These are: (1) pick your clinic collaborators carefully to ensure that the clinics have complementary skill sets and learning goals; (2) choose an appropriate client because not every client is well suited to a clinic collaboration; and (3) invest your time and build trust in the collaboration.

\section{Pick your clinic collaborators carefully}

Before starting this clinic collaboration, the three clinic directors spent time outlining for each other, and for the potential shared client, Ashoka, their respective practice areas and learning goals. They also described to each other and to Ashoka their clinic structures, including number of students, number and expertise of faculty, duration of student commitment (both in terms of semesters and credits), and academic calendars. Through this process, each clinic drafted a memo to Ashoka, identifying those areas where it had particular and unique legal competencies. We agreed in advance to try to match legal projects to a clinic's complementary areas of expertise and core competencies.

At least quarterly, the clinic directors and $\mathrm{Ng}$ meet (in person or by phone) as a group to discuss the matters that they are engaged in with Ashoka and Ashoka Fellows (within the boundary of preserving appropriate attorney-client confidentiality) as well as brainstorm new collaborative projects. This has allowed the clinic directors to avoid "reinventing" wheels in their representations of Ashoka and Ashoka Fellows. It also has allowed clinic directors to gain further understanding of and respect for the competency of its clinic collaborators.

As clinic collaborations expand, an important concern to be addressed is how best to ensure that all of the participating clinics are dedicated to and capable of delivering high quality legal advice and service to their shared clients. This becomes particularly important when and if clinics begin to collaborate as co-counsel with each other while serving a single client. One can imagine circumstances where uneven quality in the legal advice delivered by one clinic could adversely impact the reputation of all of its other collaborating clinics. One potential way to mitigate this issue is to develop clinic collaborations gradually. For example, a clinic collaboration could start 
by first working on a simulated deal before graduating to a live client. ${ }^{40}$ And even then, it may be a good idea to find "pilot" projects where the stakes are not particularly high and the deadlines for performance by the collaborating clinics are relatively relaxed.

\section{Choose an appropriate client}

Ashoka was particularly well suited for this clinic collaboration because its legal needs are significant. Moreover, as an organization that supports thousands of social entrepreneurs, Ashoka brings a network of many additional potential clients to the table. This has meant that the clinics do not need to compete for clients. Each clinic enters into a separate engagement relationship with the client it represents. Additionally, Ashoka's interest in advancing the ecosystem for social entrepreneurship contributes significantly to the success of this collaboration. For example, $\mathrm{Ng}$ visits law students in each of the three participating clinics and guest lectures in our seminars. He has introduced us to other lawyers who work in the social enterprise sector. And he has invited law students from each clinic to participate in legal webinars hosted by Ashoka. In sum, Ng has made himself available to both the clinic directors and our law students in order to assist our understanding of the legal issues that social entrepreneurs face.

There are also more intangible but equally important aspects of taking responsibility for being a "good" clinical client, which Ashoka has embodied. Ng has this to say about how he views his responsibilities as a pro bono client of this clinical collaboration:

As with any pro bono client, this means partnering with someone who, while being offered free legal services, doesn't take it for granted. This includes treating pro bono counsel (in this case, the law school clinicians) as if they were paying for legal services and recognizing pro bono legal support as a finite resource. This means being prepared, showing up on time, setting reasonable expectations, and responding to requests in a timely manner. Further, given the academic nature of a law school clinic, clients should embrace the learning component involved and do whatever he or she can to enrich the overall learning experience. This may sometimes require additional patience and providing more access to student clinicians so they can pause and reflect on why a certain decision was made or action was taken.

Ashoka is an extraordinary client, and particularly well suited-by structure and by mission - to participating in a global clinic collaboration. Finding other potential clients that are able and willing to make an investment of time and energy in a clinic collaboration may be a challenge. One potential starting point might be to look for other "network-like" organizations that, like Ashoka, can provide an introduction to multiple client engagements within their networks. Because of their membership structure, incubators and accelerators might be a good fit. Incubators and accelerators are programs that provide entrepreneurs with mentors and technical assistance, help refine business models and strategic plans, and offer start-up capital or opportunities to "pitch" to potential investors.

40 Under the leadership of one of the ITC's adjunct clinical assistant professors, Mary Rose Brusewitz, a partner with Strasburger \& Price, LLP, the ITC collaborated with the transactional clinic of law school and business school students at the Fundação Getulio Vargas, located in São Paulo, Brazil, as part of a simulation exercise to provide guidance to participants in the microfinance industry. Students from the schools worked together to draft an array of legal documents, including engagement letters, a legal memorandum explaining how a microfinance participant might structure its entry into Brazil, and a due diligence checklist. 


\section{Invest time and trust into the collaboration}

It did not take the three clinic directors long to realize that the potential benefits of this collaboration could (and should) go far beyond the scope of finding interesting clients to represent on a collaborative basis. Over the first year of this collaboration, we have learned from each other as well as from Ashoka. We often present at conferences together. We share issues and challenges that arise in our transactional clinic practices. We review each other's scholarly legal research and writing. This broader engagement came about only because each clinical director has made this collaboration a priority. When emails arrive, they are responded to promptly. When calls are placed, they are received immediately. And, the quarterly meetings we hold with Ashoka take place only on dates when all three directors are available and ready to participate.

This kind of engagement does entail a cost - a commitment of time and trust. The fruits of such a collaboration, however, far outweigh these expenditures. The intimacy forged by such a clinic collaboration has provided a safe place for the clinic directors to challenge each other and learn from each other, without lapsing into the "group think" that sometimes marks larger academic conferences and convenings. And, as this clinic collaboration matures and potentially expands to include other clinics, perhaps outside the United States, it is expected that still more benefits will accrue - to the clinics, the clients served, and the students participating in these clinics. 